\title{
INFLUENCE OF ALTITUDE ON FLEXIBILITY OF ELITE WRESTLERS GRECO-ROMAN STYLE
}

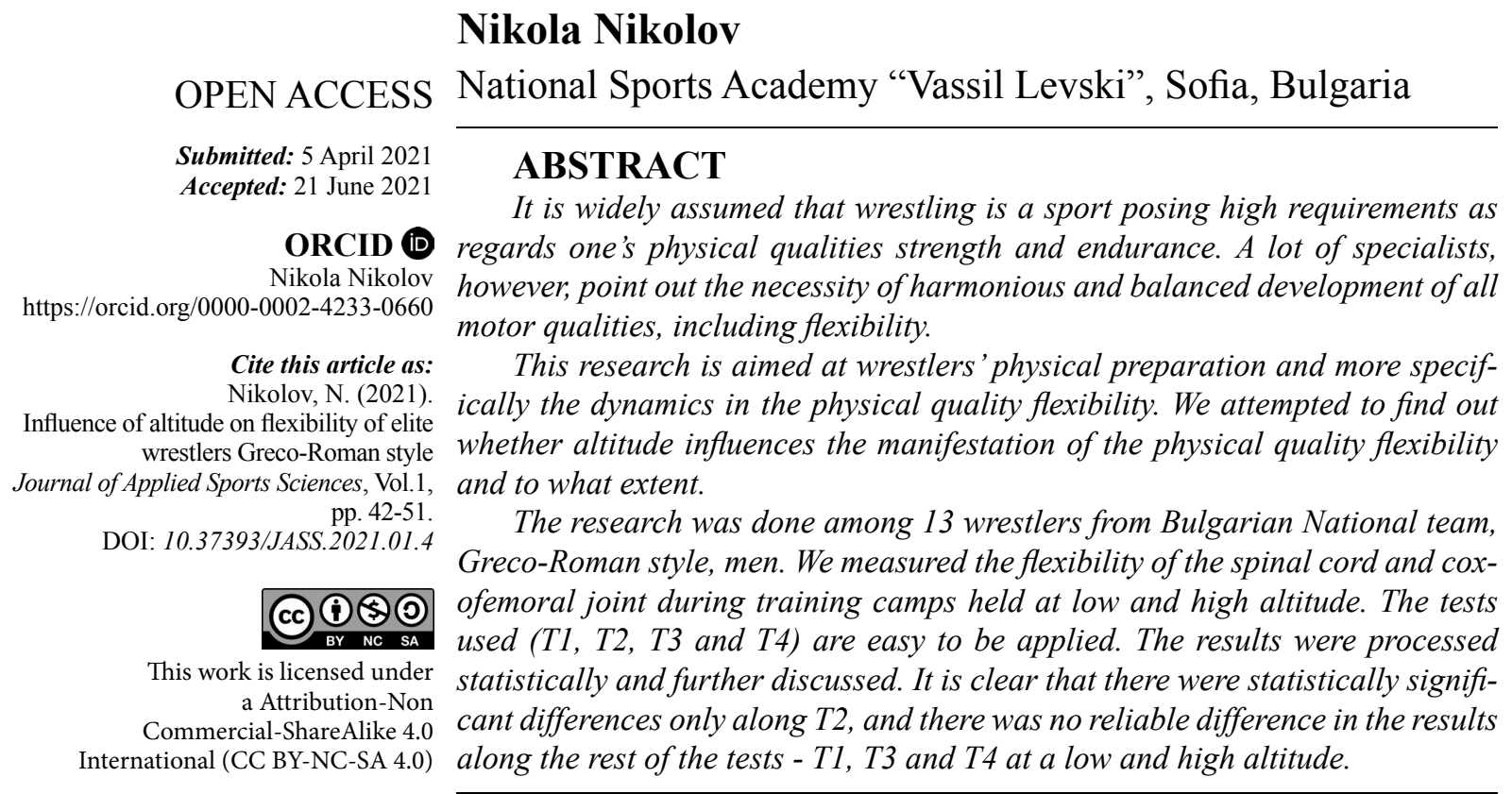

Key words: wrestling, flexibility, altitude

\section{INTRODUCTION}

Among the many factors contributing to achievement of high sports results in wrestling, technical and physical preparation are the most important ones. These sides of sports perfection are interdependent and predetermine each other. Technique contributes to the manifestation of a wrestler's physical abilities, and physical preparation increases the efficiency of the technique applied. In other words, in order to increase technical mastery, we should work not in isolation but simultaneously on the development of physical qualities. Also, there is a great potential in the forecasts about dynamics and development of both the technical side of wrestlers' preparation and the results from their physical preparation.

According to the World Sports Encyclopedia there are more than 8,000 sports disciplines. Each of them develops certain set of physical qualities and motor skills. In this sense, each motor quality can be perfected with the help of a great number of methods and means characteristic of different sports (Dimitrova, 2020).

According to a lot of authors the leading motor qualities are wrestlers' speed-strength abilities which is an emanation and involves both endurance and speed of a wrestler. We totally agree with this fact. But due to sports wrestling kinematic and dynamic nature, we should take into consideration the significance and should work on the development of coordination abilities, as well as flexibility of wrestlers.

A lot of authors have their own point of view and surveys on flexibility as one of the basic motor qualities of humans. Some of them define flexibility as the ability to perform motions with great amplitude from the joints in human body (Stanchev, 1999, 2015; Stanchev, Tsiakaras, 2004; Dasheva, Jeliazkov, 2002; Petrov, 1977; Makaveev, 1978).

Although there has not been a great attention paid to the physical quality flexibility, there 
is some research done both in Bulgaria and in other countries treating the issues related to the development, measurement, and evaluation of this motor quality. Nikolai Stanchev and Nikolai Dimitrov (1999) pointed out that wrestling was a sport with special requirements towards the quality flexibility. They stated that the mobility in all joints was very important in wrestling trainings and sports competitions, but the mobility in coxofemoral joints was of particular importance. Special flexibility is needed for execution of holds from standing position, but is also useful in ground position (Bojichkov, Stoilov, 2005). However, the dynamics in flexibility, in timely aspect, is not beneficial among the researched wrestlers aged between 19 and 21 years (Nikolov, Iliev, 2013). In their research they applied tests for measuring the flexibility of the spinal cord and coxofemoral joints of first- and second-year students at NSA "Vassil Levski" who studied at the Sports Faculty with major Freestyle and Greco-Roman wrestling and competed in their style. They were tested with the following control tests in 2013:

- ,height and length of the wrestling bridge“ - the researched individual takes a position "wrestling bridge" with his pelvis as high as possible; the feet are flat on the ground, shoulder width apart so that the bridge is stable enough. The index "height" is the measurement of the distance between the surface of the mat and the highest point of the bridge (usually in the lumbar/waist area). The measurement is made with a standard meter with an accuracy of one centimeter. The index "length" is the measurement of the distance (in $\mathrm{cm}$ ) between the line of the heels and the closest point on the head.

- „Straddle position“ - the initial position is the maximum straddle sitting position, the knees are straight. Two lines are drawn with chalk on the mat starting from the projection of the os coxae and continuing towards the feet. The measurement is done with goniometer. The degree of the angle formed between the two lines is measured with an accuracy of 1 degree.

In a survey done in 2013 the focus was on flexibility of the spinal cord because it is of great importance for taking the position "wrestling bridge" for evading critical situation and pins or as an element of some technical actions used mostly in Greco-Roman wrestling. Of course, the mobility of the shoulder grid, ankles, knees and coxofemoral joints is of great importance, too (Makaveev, 2016).

We did not manage to find other research held in low and high altitude. This was a premise for us to formulate the aim of this research: to establish whether there was a significant difference in flexibility and to offer some tests for measurement of wrestlers' specific flexibility. We also wanted to establish the dynamics in the measured flexibility and its direction.

In order to fulfil the aim of the research we set the following tasks:

$\checkmark$ Research of the available literature on the topic.

$\checkmark$ Selection of four tests for measuring active and passive flexibility in certain joints, which were easily applicable in practice but informative enough.

$\checkmark$ Selection of the subjects of the research.

$\checkmark$ Testing and collecting the results.

$\checkmark$ Analysis of the obtained results.

$\checkmark$ Formulation of conclusions and recommendations based on the obtained results.

In order to fulfil the aim of the research we surveyed the available literature and, on this basis, selected four tests measuring active and passive flexibility in certain joints. The tests are easily applicable in practice and informative enough.

\section{METHODS}

\section{Participants}

Because this research focused on the physical preparation of elite Greco-Roman style 
wrestlers and especially on their flexibility, the researched individuals were part of the male Bulgarian Greco-Roman Wrestling National team, competing in the age group 20 years. The mean age of the participants was 25 years - the youngest two wrestlers were 21 and the oldest one was 36 . The wrestlers' training experience varied from 10 years to 20 years. The research was done among 15 individuals but the data about only 13 of them were processed after the first and second measurement.

\section{Design}

The first testing was done during the preparatory period of the team. We took the measurements of 15 people on 10.09.2020 at the sports facilities of Dianabad in Sofia. The second testing was done at the end of the preparatory period, in the training camp (16.09.2020-07.10.2020) at High Mountain Sports Facilities “Belmeken”. The second testing was carried out at the end of the preparation at the sports facilities in Belemken which is situated on 2,050 meters altitude. (As we have already mentioned, 13 people took part in both tests - at a low and high altitude and that is why only 13 people's measurements were analyzed).

Both surveys were done during the first training session for the day (at about 11 a.m.), right after the usual warm-up including general and specific wrestling exercises, and parallel with the work in the main part of the training session designed by the coaches of the team. One pair was summoned at a time for the testing. The rest of the competitors were performing the tasks from the main part of their training session. The aim of the analysis was to evaluate the presence or absence of the achieved results from the 4 tests during the preparation at a low and high altitude.

\section{Statistical analysis}

The data were presented in a table format. The results were processed with MS Excel 2016. In order to establish whether there was a significance difference in the results from the tests we performed a normality check of the distribution of the data and applied a test for hypotheses check for two dependent samples. In this case, we used variation analysis; $t$-test of Student for two dependent samples; Jarque-Bera test for normality of distribution of the data.

The measurements were made with a standard meter, in centimeters with an accuracy of one centimeter.

We used four tests:

$\checkmark$ Test 1 (T1) - from lying position; palms are on the shoulders; a gradual raise of the torso as high as possible; the head is raised to the highest position too (Figure 1). The distance between the support and chin (the active flexibility of the spinal cord) is measured.

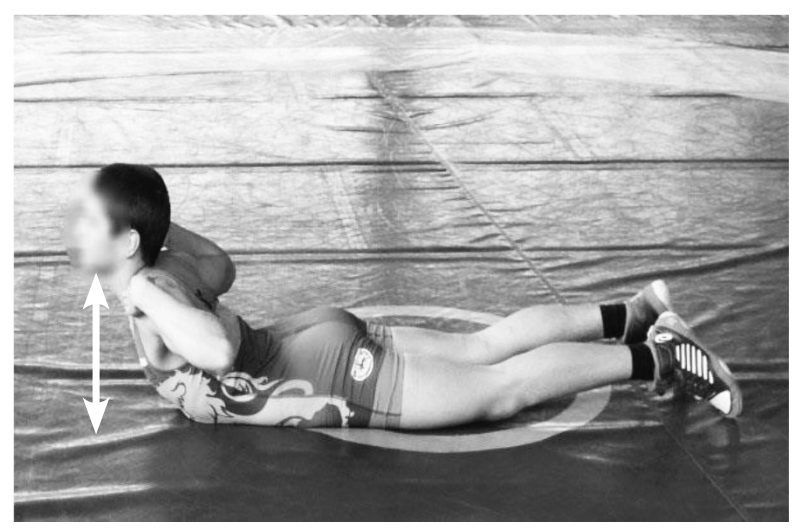

Figure 1. Test for measurement of the active flexibility of the spinal cord - T1 
Test 2 (T2) - the same as in T1 but with sive flexibility). some help from a partner - Figure 2 (pas-

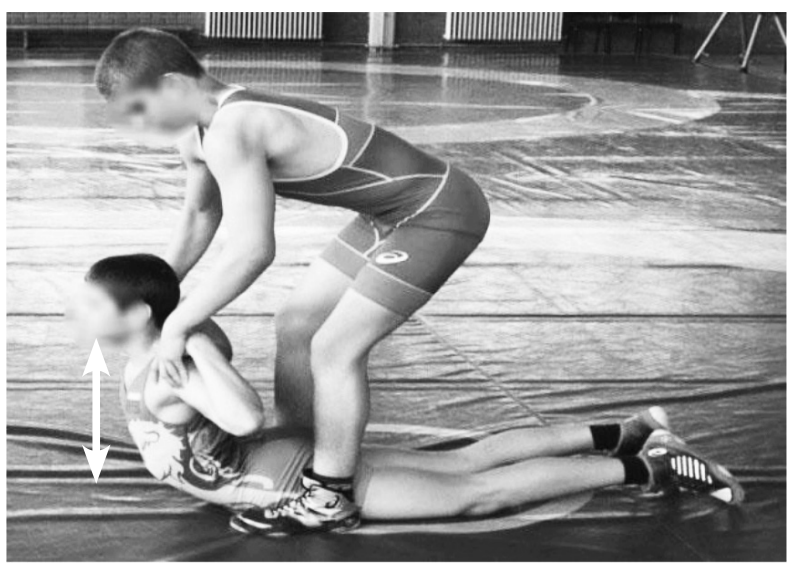

Figure 2. Test for measurement of the passive flexibility of the spinal cord - T2

$\checkmark$ Test 3 (T3) - from lying position; arms up; highest position, the distance between the the right leg is raised/extended in the coxofemoral joint; the knee is straight; the pelmat and the proximal end of the kneecap is vis is pinned to the mat (Figure 3). At the measured (active flexibility).

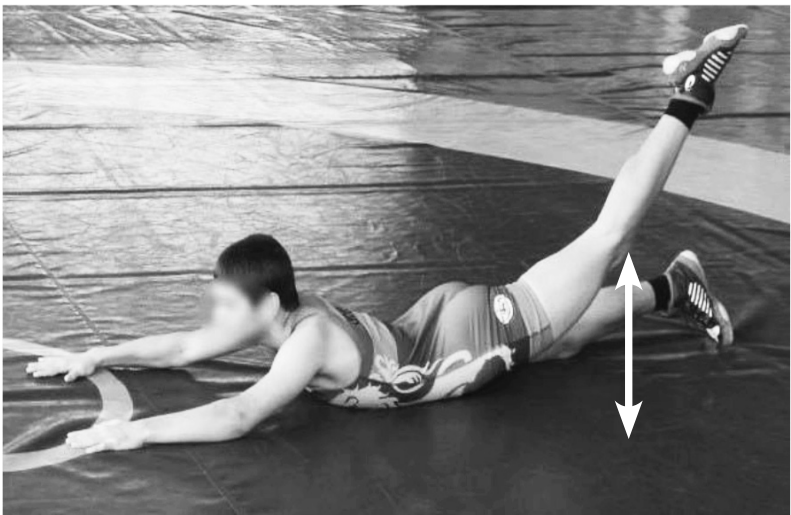

Figure 3. Test for measurement of the active flexibility of the coxofemoral joint - T3

$\checkmark$ Test 4 (T4) - the same as in T3, but with individual. With the other hand he holds the some help from a partner. The partner places one hand on the waist of the researched thigh and helps the raise (passive flexibility).

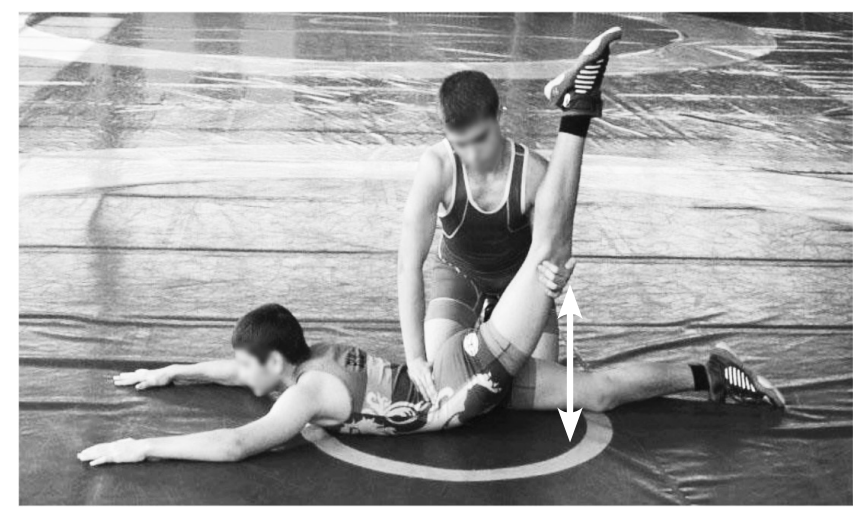

Figure 4. Test for measurement of the passive flexibility of the coxofemoral joint - T4 


\section{RESULTS}

The tests and the obtained results are shown in Table $1-$ for the tests done in Sofia, and in
Table 2 - for the tests done at the end of the preparatory period at a high altitude.

Table 1. Results from the tests at a low altitude (in $\mathrm{cm}$ )

\begin{tabular}{cccccc}
\hline Subjects & Name/w.cat. & Test 1 & Test 2 & Test 3 & Test 4 \\
\hline 1 & N.P./ 55 & 27 & 51 & 23 & 42 \\
2 & I.A./ 60 & 26 & 50 & 27 & 37 \\
3 & D.D./ 67 & 35 & 74 & 30 & 45 \\
4 & S.K./ 77 & 27 & 62 & 18 & 40 \\
5 & D.A./ 77 & 35 & 69 & 24 & 37 \\
6 & A.M./77 & 29 & 67 & 24 & 40 \\
7 & Z.Z./ 82 & 30 & 68 & 28 & 39 \\
8 & R.D./ 82 & 35 & 58 & 12 & 36 \\
9 & S.N./ 87 & 28 & 70 & 19 & 40 \\
10 & Y.D./ 87 & 32 & 73 & 24 & 39 \\
11 & T.A./ 87 & 36 & 65 & 26 & 28 \\
12 & M.M./ 97 & 34 & 80 & 30 & 49 \\
13 & K.M./97 & 37 & 61 & 27 & 44 \\
\hline
\end{tabular}

Table 2. Results from the tests at a high altitude (in $\mathrm{cm}$ )

\begin{tabular}{cccccc}
\hline Subjects & Name/w.cat. & Test 1 & Test 2 & Test 3 & Test 4 \\
\hline 1 & N.P./ 55 & 28 & 74 & 30 & 42 \\
2 & I.A./ 60 & 27 & 56 & 44 & 50 \\
3 & D.D./ 67 & 32 & 70 & 20 & 38 \\
4 & S.K./ 77 & 25 & 65 & 20 & 42 \\
5 & D.A./ 77 & 34 & 67 & 35 & 38 \\
6 & A.M./77 & 27 & 62 & 20 & 31 \\
7 & Z.Z./ 82 & 30 & 65 & 23 & 42 \\
8 & R.D./ 82 & 36 & 66 & 20 & 42 \\
9 & S.N./ 87 & 27 & 70 & 17 & 37 \\
10 & Y.D./ 87 & 36 & 76 & 37 & 53 \\
11 & T.A./ 87 & 38 & 80 & 31 & 40 \\
12 & M.M./ 97 & 36 & 83 & 31 & 51 \\
13 & K.M./97 & 36 & 70 & 29 & 45 \\
\hline
\end{tabular}

Table 3 presents the data recorded from the two tests which were statistically processed. Thirteen individuals were tested with test 1 . The mean value of the researched index was 31.66. The minimal value was 26 , and the maximal one -37 . The most frequently measured result among the researched individuals was $35 \mathrm{~cm}$. The values were relatively homogeneous $(\mathrm{V}=12.42 \%)$. The distribu- tion of the data was normal (JB test $=1.68$ $<5.99$ ). Jarque-Bera test was calculated automatically by the program, after that the results were written down and compared to the preliminarily set values, thus verifying that the distribution of the values was normal, i.e. below the standard value. This allowed us to use the $t$-test of Student for two dependent samples. 
Table 3. Statistical indexes obtained after the comparison of the first and second testing

\begin{tabular}{lcccccccc}
\hline & T1 & T1 & T2 & T2 & T3 & T3' & T4 & T4' \\
\hline Mean & 31.66 & 31.69 & 65.23 & 69.54 & 24 & 27.46 & 39.69 & 42.38 \\
Standard Error & 1.09 & 1.26 & 2.43 & 2.05 & 1.42 & 2.27 & 1.40 & 1.71 \\
Median & 32 & 32 & 67 & 70 & 24 & 29 & 40 & 42 \\
Mode & 35 & 36 & $\#$ N/A & 70 & 24 & 20 & 40 & 42 \\
Standard Deviation & 3.93 & 4.53 & 8.75 & 7.38 & 5.13 & 8.20 & 5.04 & 6.16 \\
Sample Variance & 15.42 & 20.56 & 76.53 & 54.44 & 26.33 & 67.27 & 25.40 & 37.92 \\
Kurtosis & -1.75 & -1.76 & -0.26 & 0.02 & 1.18 & -0.53 & 1.98 & -0.09 \\
Skewness & -0.19 & -0.09 & -0.35 & 0.19 & -1.10 & 0.54 & -0.49 & 0.20 \\
Range & 11 & 13 & 30 & 27 & 18 & 27 & 21 & 22 \\
Minimum & 26 & 25 & 50 & 56 & 12 & 17 & 28 & 31 \\
Maximum & 37 & 38 & 80 & 83 & 30 & 44 & 49 & 53 \\
Sum & 411 & 412 & 848 & 904 & 312 & 357 & 516 & 551 \\
Count & 13 & 13 & 13 & 13 & 13 & 13 & 13 & 13 \\
\hline
\end{tabular}

In T1 the mean value of the measured in- The measured values were relatively homogedex was approximately equal to 32 . The min- neous $(\mathrm{V}=14.31 \%)$. The distribution of the imal value was 25 , and the maximal one -38 . data was normal $(\mathrm{JB}$ test $=1.69<5.99)$.

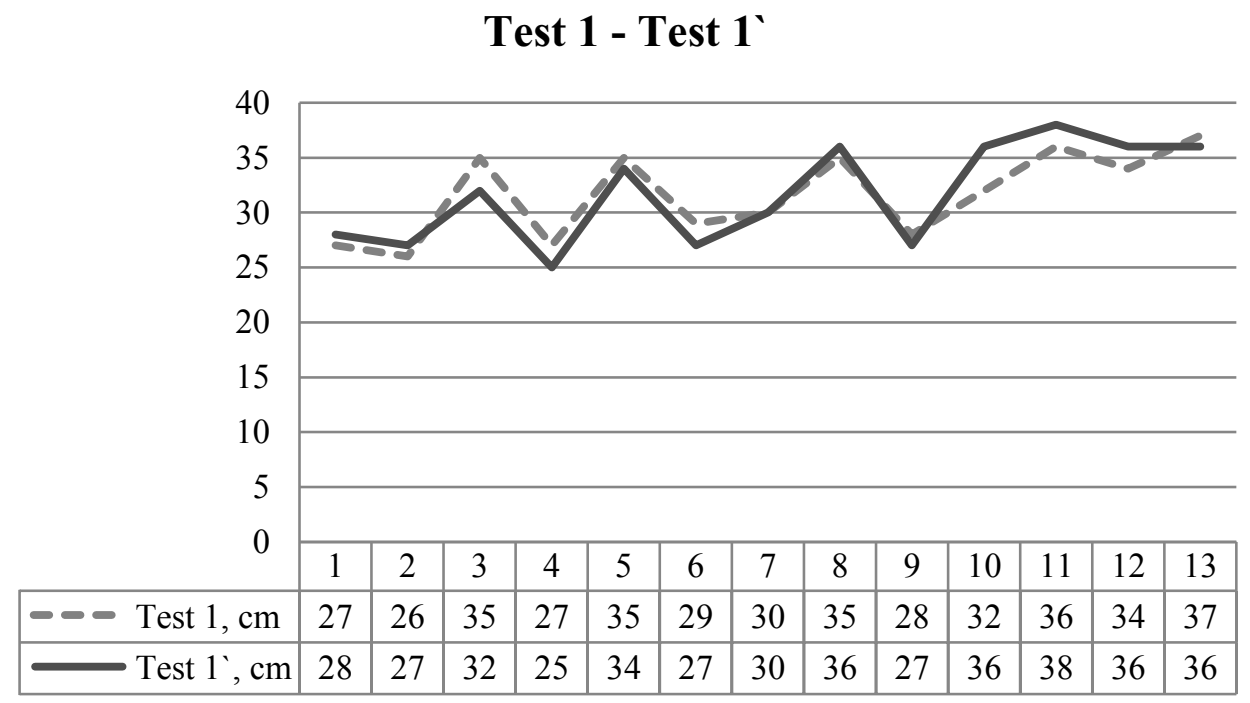

Figure 5. Curve of the data obtained after the comparison of the mean values of the researched individuals after the first and second testing with T1

We applied the $t$-test of Student for two dependent samples at significance level $95 \%(\alpha=$ 0.05 ). With $95 \%$ guarantee probability we can claim that there was no statistically significant difference between the obtained mean values of the two tests held at low and high altitude $(\mathrm{P}(\mathrm{T})=0.44>0.05)$.
We can see in Table 3 that the mean value of the measured index (passive flexibility of the spinal cord) in T2 equaled 65 . The minimal value was 50 , the maximal one -80 . The measured values were relatively homogeneous $(\mathrm{V}=13.41 \%)$. The distribution of the data was normal $(\mathrm{JB}$ test $=0.29<5.99)$. 
Also, in T2', the mean value of the measured index was approximately equal to 70 . There was a significant difference between the maximal and minimal value of the index (27). The minimal value was 56 , the max- imal one -83 . The measured values were relatively homogeneous $(\mathrm{V}=10.61 \%)$. The distribution of the data was normal (JB test $=0.08<5.99$ ).

\section{Test 2 - Test 2'}

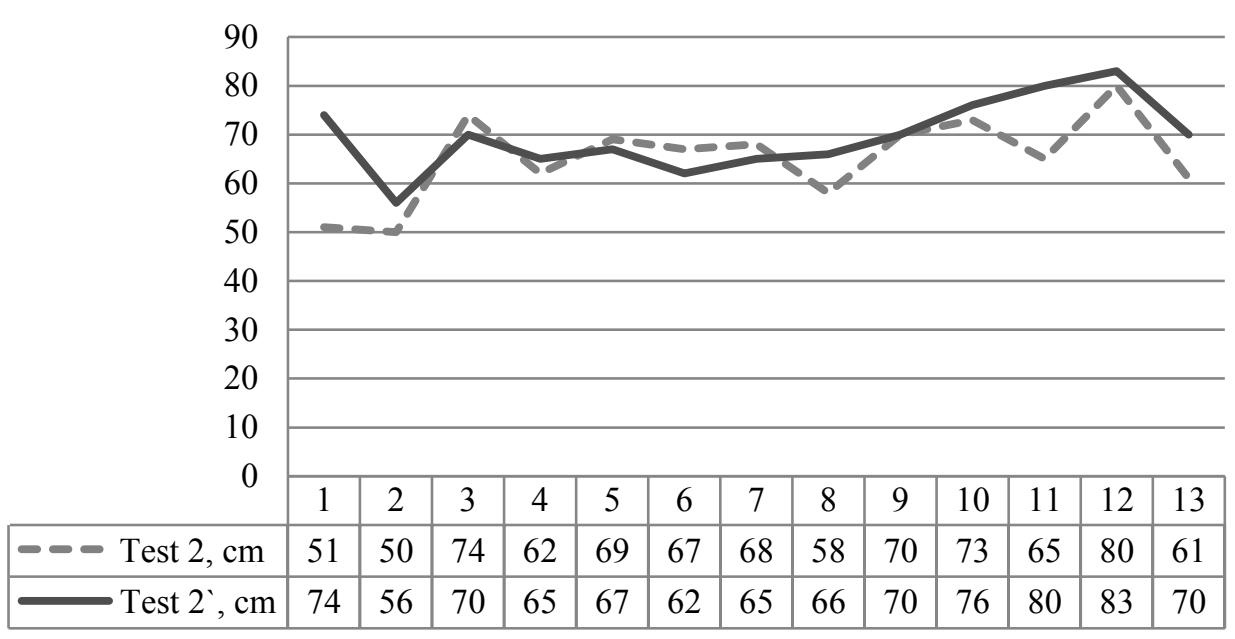

Figure 6. Curve of the data obtained after the comparison of the mean values of the researched individuals after the first and second testing with T2

We applied the $t$-test of Student for two dependent samples at significance level of $95 \%(\alpha=0.05)$. With 95\% guarantee probability we can claim that there was a statistically significant difference between the obtained mean values of the two tests - before and after the preparation $(\mathrm{P}(\mathrm{T})=0.04<0.05)$.

The individual differences between test 1 and test 2 provide the difference between the active and passive flexibility of the spinal cord, which is specific for wrestlers, mainly competing in Greco-Roman style, because the efficient holds and the wrestling bridge require a very good level of flexibility in this area (Stanchev, Tsiakaras, 2004). In the conducted testing at low altitude the results were in favor of the passive flexibility. The differences in the data about each wrestler provide us with some information about the so-called spare flexibility. The bigger the values, the greater the potential for development of active flexibility, and vice versa. The interpretations of the differences in the individual data of the wrestlers from $\mathrm{T} 1{ }^{\prime}$ and $\mathrm{T} 2{ }^{\prime}$ were analogical but from the tests at high altitude.

In T3, the mean value of the measured index (active flexibility of the coxofemoral joint) was 24 . The minimal value was 12 , and the maximal one -30 . The measured values were relatively homogeneous $(\mathrm{V}=21.38 \%)$. The distribution of the data was normal (JB test $=3.38<5.99$ ).

In T3', the mean value of the measured index was approximately equal to 27 . There was a significant difference between the minimal and maximal value of the index (27). The minimal value was 17 , and the maximal one -44 . The participants in the test showed relatively homogeneous results $(\mathrm{V}=29.87 \%)$. The distribution of the data was normal (JB test $=0.78<5.99$ ). 


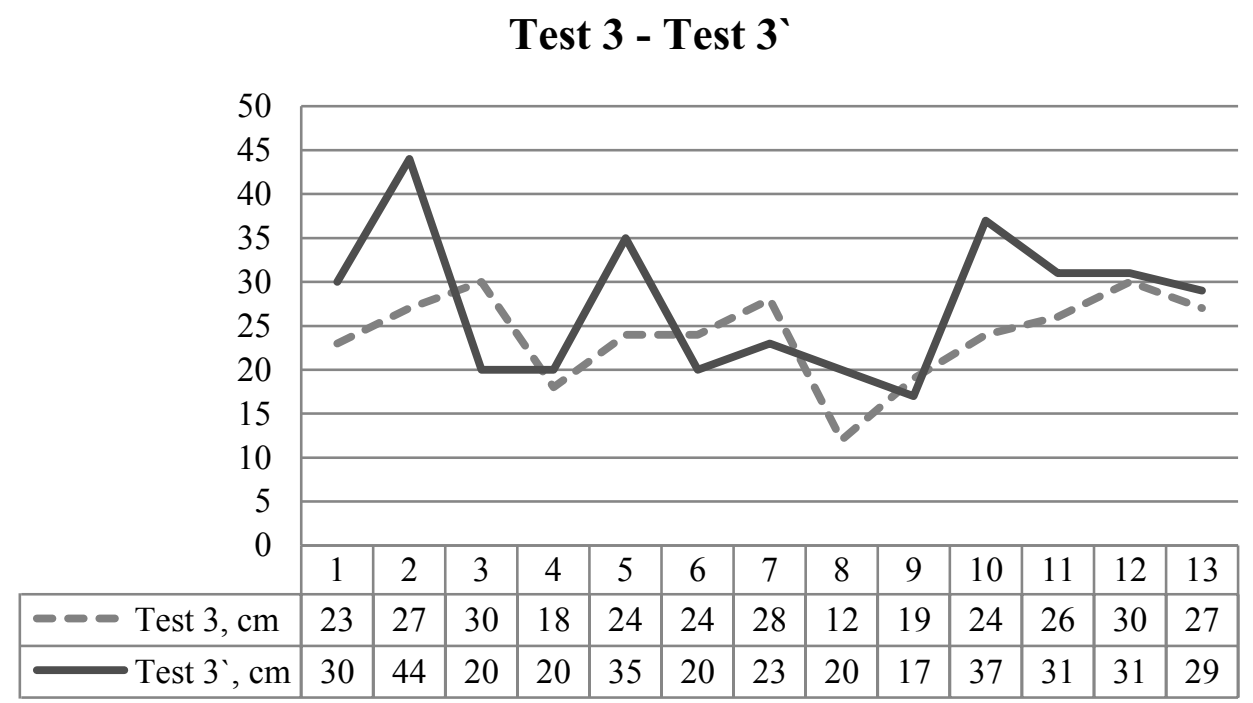

Figure 7. Curve of the data obtained after the comparison of the first and second testing with T3

We applied the $t$-test of Student for two dependent samples at a level of significance $95 \%$ ( $\alpha=0.05$ ). With $95 \%$ guarantee probability we can claim that there was no statistically significant difference between the obtained mean values from the two tests before and after the preparation $(\mathrm{P}(\mathrm{T})=0.06>0.05)$.

In $\mathrm{T} 4$ the mean value of the measured index (passive flexibility of the coxofemoral joint) was approximately equal to 40 . There was a significant difference between the maximal and minimal values of the index (21).
The minimal value was 28 , and the maximal one -49 . The measured values were homogeneous $(\mathrm{V}=12.70 \%)$. The distribution of the data was normal (JB test $=2.65<5.99$ ).

In T4 the mean value of the measured index was approximately equal to 42 . There was a significant difference between the maximal and minimal values of the index (22). The minimal value was 31 , and the maximal one -53 . The participants in the test showed relatively homogeneous results $(\mathrm{V}=14.53 \%)$. The distribution of the data was normal $(\mathrm{JB}$ test $=0.09<5.99)$.

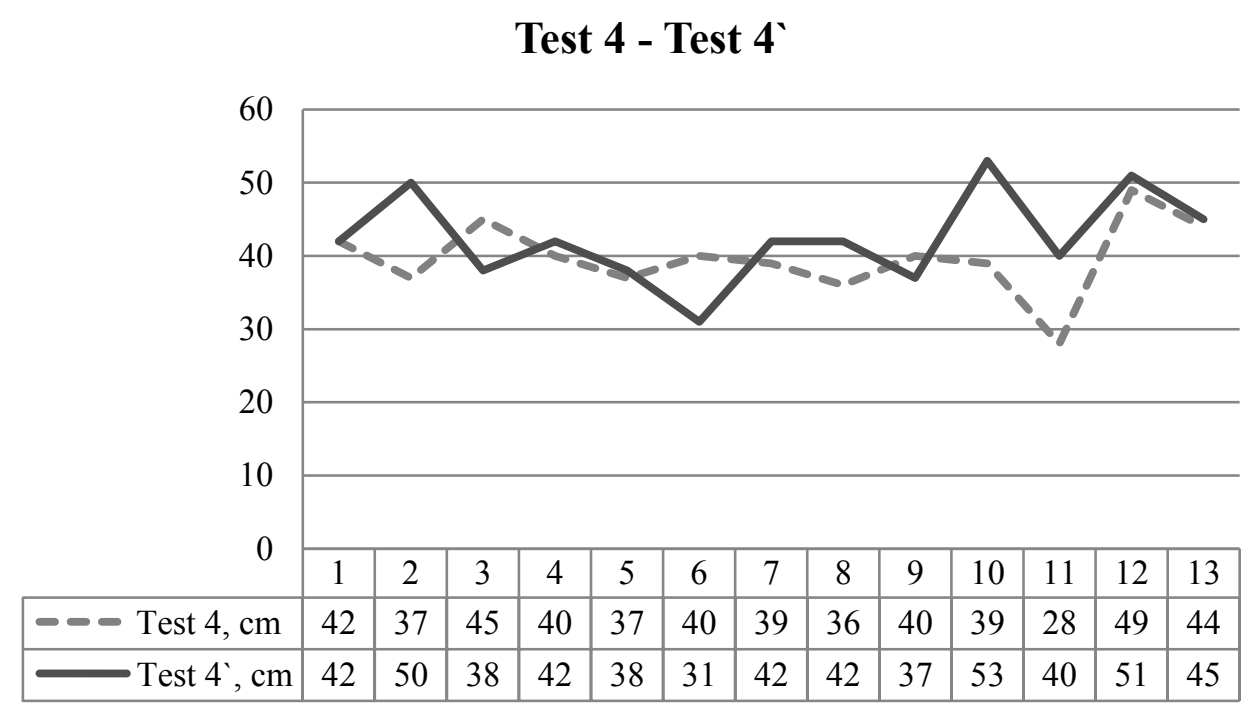

Figure 8. Curve of the data obtained after the comparison of the mean values of the researched individuals after the first and second testing with T4 
We applied the Student's $t$-test for two dependent sample at a significance level of $95 \%$ $(\alpha=0.05)$. With $95 \%$ guarantee probability we can claim that there was no statistically significant difference between the obtained mean values from the two tests before and after the preparation $(\mathrm{P}(\mathrm{T})=0.10>0.05)$.

\section{DISCUSSION}

From the tests done, only in T2 (raising the body with the help of a partner) there was a statistically reliable difference between the mean values of the obtained results at low and high altitude. This, however, does not mean that the reason is the preparation at high altitude but is a premise for further, more detailed surveys of the reason for this difference in positive aspect.

Although in the four tests the results of the researched individuals (the team) were relatively homogeneous, which is explicable given the close indexes of the sample (gender, age group, sports experience, etc.), there is still a significant difference between the minimal and the maximal values of the indexes along most of the tests which can be explained with the great individual differences of the wrestlers as regards both their flexibility in general and their anatomic peculiarities, stature, weight category, age, etc.

In tests 3-3' and 4-4' there were relatively greater individual fluctuations between the values of the wrestlers. In tests 3-3` nine wrestlers showed improved values and four - lower values. In tests 4-4` nine wrestlers improved their indexes, one had the same result, and three lowered their indexes. Such a trend and distribution were shown in the first three tests but not with such a great amplitude of the individual results. The explanation could be related to the fact that the first two tests measure types of flexibility of the spinal cord which is developed purposefully with particular means in wrestlers' preparation - throws of a dummy from the chest area, wrestling bridges, falls and overturns in bridge position, etc. In tests 3 and 4 the flexibility of the coxofemoral joints is measured, which is not an object of purposeful development in the training process of Greco-Roman wrestling style. As regards the results obtained from the tests performed with a partner which provide the values of the passive flexibility (T2 and T4), we find the higher results normal because, as theory and practice show, the passive flexibility is always greater than the active one. Passive flexibility is important in wrestling because of the nature of sport. There is almost always a contact between the two competitors where passive flexibility is manifested.

\section{CONCLUSION}

The obtained data and the analysis and conclusions are indicative only to the subjects researched and we could not extrapolate them to other wrestlers. But we could not claim that the dynamics, and especially the increase in the data, the way it is (e.g. T2) is due only to the change in the altitude although the training sessions at high altitude had their influence. That is why we believe these data could be a step towards further, comprehensive, more indepth research of the influence of altitude on wrestlers' flexibility. The tests used are easy to be applied, and the information obtained from them could be useful for both coaches and other specialists - sports pedagogues and researchers.

\section{Acknowledgement}

We would like to express our gratitude to the head coach of the National Greco-Roman Wrestling Team (men) Armen Nazarian, as well as to his assistant coaches Bisser Georgiev, Iliyan Georgiev, and Elis Guri. Without their cooperation we would not have been able to conduct this research. 


\section{REFERENCES}

Bozhichkov, A., Stoilov R. (2005). Sambo. Sofia. // Божичков, А., Стоилов Р. (2005). Самбо. София.

Dimitrova, N. (2020). Motivatsionna struktura za evropeyski proekt, „Dzhudo v uchilishte“. Vocational Education. Volume 22, Number 3, pp. 266-275 // Димитрова, Н. (2020). Мотивационна структура за европейски проект „Джудо в училище“. Vocational Education. Volume 22, Number 3, c. 266-275

Makaveev, O. (1978). Kontrolni normativi i postizhenia $\mathrm{v}$ borbata. Trenyorska misal, Number 8, pp. 3-10. // Макавеев, О. (1978). Контролни нормативи и постижения в борбата. Треньорска мисьл, Брой 8, с. 3-10.

Makaveev, R. (2016). Borba - kontrol na podgotovkata. Monograph. NSA Pres. Sofia. // Макавеев, Р. (2016). Борба - контрол на подготовката. Монография. НСА Прес. София.

Nikolov, N., Iliev, I. (2013). Dinamika na fizicheskoto kachestvo gavkavost v ednogodishen period pri studenti, spetsialisti po borba. Sport i nauka, izv. Broy 4, s. 38. // Николов, Н., Илиев, И. (2013). Динамика на физическото качество гъвкавост в едногодишен период при студенти, специалисти по борба. Спорт и наука, изв. Брой 4, с. 38.

Petrov, R. et al. (1977). Svobodna i klasicheska borba, Meditsina i Fizkultura, Sofia. // Петров, Р. и кол. (1977). Свободна и класическа борба, Медицина и Физкултура, София.
Rachev, Kr. (1977). Teoria i metodika na fizicheskoto vazpitanie. Meditsina i Fizkultura. Sofia. // Рачев, Кр. (1977). Теория и методика на физическото възпитание. Медицина и Физкултура. София.

Stanchev, N. (2015). Fizicheski kachestva na boretsa. NSA PRES, Sofia. // Станчев, Н. (2015). Физически качества на бореиа. НСА ПРЕС, София.

Stanchev, N., Dimitrov, N. (1999). Podobryavane na podvizhnostta $\mathrm{v}$ tazobedrenite stavi pri 17-19-godishni sastezateli po klasicheska borba. Sport i nauka, br. 2, s. 52. // Станчев, Н., Димитров, Н. (1999). Подобряване на подвижността в тазобедрените стави при 17-19-годишни състезатели по класическа борба. Спорт и наука, бр. 2, с. 52.

Stanchev, N., Tsiakaras, N. (2004). Eksperimentalna metodika za podobryavane na gavkavostta na grabnachnia stalb pri 16-18-godishni bortsi po klasicheska borba-R. Gartsia.Sbornikdokladiotnauchnakonferentsia na katedra „,Borba i judo”, pp. 47. // Станчев, Н., Циакарас, Н. (2004). Експериментална методика за подобряване на гъвкавостта на гръбначния стълб при 16-18-годишни борци по класическа борба - Р. Гърция. Сборник доклади от научна конференщия на катедра „Борба и джудо”, с. 47.

Zhelyazkov, Tsv., Dasheva, D. (2002). Osnovi na sportnata trenirovka. Gera Art, Sofia.// Желязков, Цв., Дашева, Д. (2002). Основи на спортната тренировка. Гера Арт, София.

\section{Corresponding author:}

Nikola Nikolov

Department "Wrestling and Judo" National Sports Academy "Vassil Levski" Studentski grad, 21, Acad. Stefan Mladenov str. Sofia 1700, Bulgaria E-mail: koki_1979@abv.bg 